\title{
Surgical treatment of aggressive vertebral hemangiomas
}

\author{
Viren S. Vasudeva, MD, ${ }^{1}$ John H. Chi, MD, MPH, ${ }^{1,2}$ and Michael W. Groff, MD ${ }^{1,2}$ \\ 'Brigham and Women's Hospital, Harvard Medical School; and ²Center for Neuro-Oncology, Dana-Farber Cancer Institute, \\ Boston, Massachusetts
}

\begin{abstract}
OBJECTIVE Vertebral hemangiomas are common tumors that are benign and generally asymptomatic. Occasionally these lesions can exhibit aggressive features such as bony expansion and erosion into the epidural space resulting in neurological symptoms. Surgery is often recommended in these cases, especially if symptoms are severe or rapidly progressive. Some surgeons perform decompression alone, others perform gross-total resection, while others perform en bloc resection. Radiation, embolization, vertebroplasty, and ethanol injection have also been used in combination with surgery. Despite the variety of available treatment options, the optimal management strategy is unclear because aggressive vertebral hemangiomas are uncommon lesions, making it difficult to perform large trials. For this reason, the authors chose instead to report their institutional experience along with a comprehensive review of the literature.
\end{abstract}

METHODS A departmental database was searched for patients with a pathological diagnosis of "hemangioma" between 2008 and 2015. Medical records were reviewed to identify patients with aggressive vertebral hemangiomas, and these cases were reviewed in detail.

RESULTS Five patients were identified who underwent surgery for treatment of aggressive vertebral hemangiomas during the specified time period. There were 2 lumbar and 3 thoracic lesions. One patient underwent en bloc spondylectomy, 2 patients had piecemeal gross-total resection, and the remaining 2 had subtotal tumor resection. Intraoperative vertebroplasty was used in 3 cases to augment the anterior column or to obliterate residual tumor. Adjuvant radiation was used in 1 case where there was residual tumor as well. The patient who underwent en bloc spondylectomy experienced several postoperative complications requiring additional medical care and reoperation. At an average follow-up of 31 months (range 3-65 months), no patient had any recurrence of disease and all were clinically asymptomatic, except the patient who underwent en bloc resection who continued to have back pain.

CONCLUSIONS Gross-total resection or subtotal resection in combination with vertebroplasty or adjuvant radiation therapy to treat residual tumor seems sufficient in the treatment of aggressive vertebral hemangiomas. En bloc resection appears to provide a similar oncological benefit, but it carries higher morbidity to the patient.

http://thejns.org/doi/abs/10.3171/2016.5.FOCUS16169

KEY WORDS aggressive vertebral hemangioma; vertebral hemangioma; cavernous hemangioma; vertebral angioma; primary spinal column tumor

$\mathrm{V}$ ERTEBRAL hemangiomas are benign vasoformative neoplasms of endothelial cells that grow within marrow spaces in the bone and encase bony trabeculae. They are generally considered neoplasms, but due to the lack of aggressive histopathological features, some authors have referred to them as hamartomas or vascular malformations. ${ }^{32,37,45,72}$ There is at least one associated genetic rearrangement that has been described resulting in a new fusion gene, EWSRI-NFATC1, which suggests that vertebral hemangiomas may in fact be neoplasms, but this remains controversial..$^{5}$ In the majority of patients, these lesions remain asymptomatic and do not require any treatment or surveillance. In $0.9 \%-1.2 \%$ of patients, however, the lesions can cause symptoms due to neural compression as a result of bone expansion, erosion through cortex, fracture, or hematoma. ${ }^{8,19,24,27,52-54}$ These Enneking Stage 3 lesions - which are termed "aggressive vertebral hemangiomas" - are more likely than their asymptomatic counterparts to involve the entire vertebral body, extend into the posterior elements, and have an irregular honeycomb pattern with lytic areas on radiological evaluation..$^{21,29,50}$ The presenting symptoms are dependent on the location of the tumor and the degree of spinal cord or nerve root compression. ${ }^{10}$ Female patients may be more prone to become symptomatic during the last trimester of pregnancy, presumably due to the hemodynamic effects of a gravid 
uterus. ${ }^{12,48,51,59,61,64,67}$ Aggressive vertebral hemangiomas are also more common in adults but have been reported in children as well. ${ }^{11,18,44,54}$

It is generally agreed that surgical intervention is warranted when hemangiomas cause pain or neurological symptoms, however the optimal treatment strategy is controversial. ${ }^{1,31}$ Some surgeons have used less-invasive strategies, such as vertebroplasty, endovascular or percutaneous embolization, ethanol injection, and radiation therapy. Others recommend surgery in the form of decompression, gross-total resection, or even en bloc resection. Because of the relative infrequency of these lesions and sparse reporting in the literature, there are few studies with long-term follow-up that directly compare treatment modalities. Also, some authors reported on a heterogeneous group of patients who had local pain referable to intracompartmental vertebral hemangiomas without neural compression or aggressive features.$^{50}$ For this reason, we feel it is important to publish our own institutional experience along with a thorough review of the literature.

\section{Methods}

A departmental database was searched for all patients who underwent surgery and had a pathological diagnosis of "hemangioma" between 2008 and 2015. Medical records and radiology studies were retrospectively reviewed to identify patients with aggressive vertebral hemangiomas. All patients underwent both CT and MRI routinely. In cases where the diagnosis was uncertain based on the imaging studies, a biopsy was performed to rule out other diagnoses that might require different treatment. All patients in this series underwent surgery for subtotal resection, gross-total resection, or en bloc resection, and preoperative embolization was performed when appropriate. Patients with mechanical instability of the spinal column following resection underwent concurrent instrumented fusion. In some cases in which a partial vertebrectomy was necessary for resection of the tumor, intraoperative vertebroplasty was used to augment the load-sharing capacity of the remaining vertebral body. In other cases in which a complete vertebrectomy was performed, a structural cage was placed. Patients with spinal tumors are managed by a multidisciplinary team of neurosurgeons, orthopedic surgeons, oncologists, and radiation oncologists at our institution. This team determined whether patients underwent adjuvant radiation therapy and at what dose. When reviewing patient records, information was collected regarding age, sex, location of the tumor, preoperative embolization, surgical technique, spinal reconstruction, estimated blood loss (EBL), complications, and recurrence. The patient's clinical status at follow-up was also recorded.

\section{Results}

Five patients who underwent surgical treatment of aggressive vertebral hemangiomas were identified. In this series, 4 patients were female and 1 was male. The mean age at the time of surgery was 51.4 years (range 30-71 years). Four patients presented with neurological deficits that were referable to the hemangioma, and 1 patient presented with worsening back pain postpartum. Neurological defi- cits included radiculopathy, myelopathy, and neurogenic claudication. Imaging in all patients demonstrated aggressive features such as involvement of the entire vertebral body, extension into the posterior elements, expansion of bone, and epidural extension. Two lesions were located in the lumbar spine and 3 were located in the thoracic spine.

Two patients underwent percutaneous biopsy prior to surgery. Four patients were treated with preoperative embolization to minimize bleeding during the operation. All surgeries were performed from a posterior-only approach. In 2 cases, subtotal resection was performed with a goal of decompressing the thecal sac; in 2 cases, piecemeal gross total resection was performed; and in 1 case, en bloc spondylectomy was performed. Both of the patients who underwent gross-total resection and one of the patients who underwent subtotal resection had intraoperative vertebroplasty (Fig. 1). Four patients required an instrumented fusion at the time of surgery to prevent the possibility of iatrogenic instability. The patient who underwent en bloc resection also required anterior column reconstruction with a titanium cage (Fig. 2). One patient (Case 5) who underwent piecemeal gross-total resection did not require instrumented fusion. Estimated blood loss was recorded in 4 of the 5 cases and ranged from 400 to $500 \mathrm{ml}$ for patients who underwent subtotal or gross-total resection. The EBL for the patient (Case 1) who underwent en bloc spondylectomy was $1800 \mathrm{ml}$. This patient was also the only patient who experienced early or late complications as a result of surgery (Table 1).

One patient (Case 2), the patient who underwent subtotal resection but did not require vertebroplasty, received fractionated proton radiotherapy (45 Gy in 25 fractions) (Fig. 3). Patients were followed for an average of 31 months (range 3-65 months). No patient has experienced clinical or radiographic recurrence, and all of the patients' symptoms have resolved, except for the patient who underwent en bloc resection, who continues to have back pain.

\section{Illustrative Case}

A 45-year-old female (Case 5) presented with rightsided flank pain consistent with a thoracic radiculopathy. She underwent a CT scan and subsequent MRI, which revealed an aggressive vertebral hemangioma centered within the T- 8 vertebral body with bony and soft tissue extension into the spinal canal and right T8-9 neural foramen (Fig. 4).

Because her symptoms were due to a focal bony prominence displacing the right T- 8 nerve root, it was felt that nonoperative treatment modalities, including radiation, embolization, vertebroplasty, or ethanol injection, would not be useful as stand-alone therapies. Surgery was therefore scheduled to resect the lesion with preoperative embolization under the same anesthesia to minimize the risk of blood loss.

On the day of surgery, an angiogram was performed for embolization. During the angiogram a hypervascular blush was observed at the T- 8 vertebral body with supply from both the right and left T- 8 segmental arteries. The embolization was completed with coils and $N$-butyl cyanoacrylate (NBCA), and following this the hypervascular blush was no longer seen. 

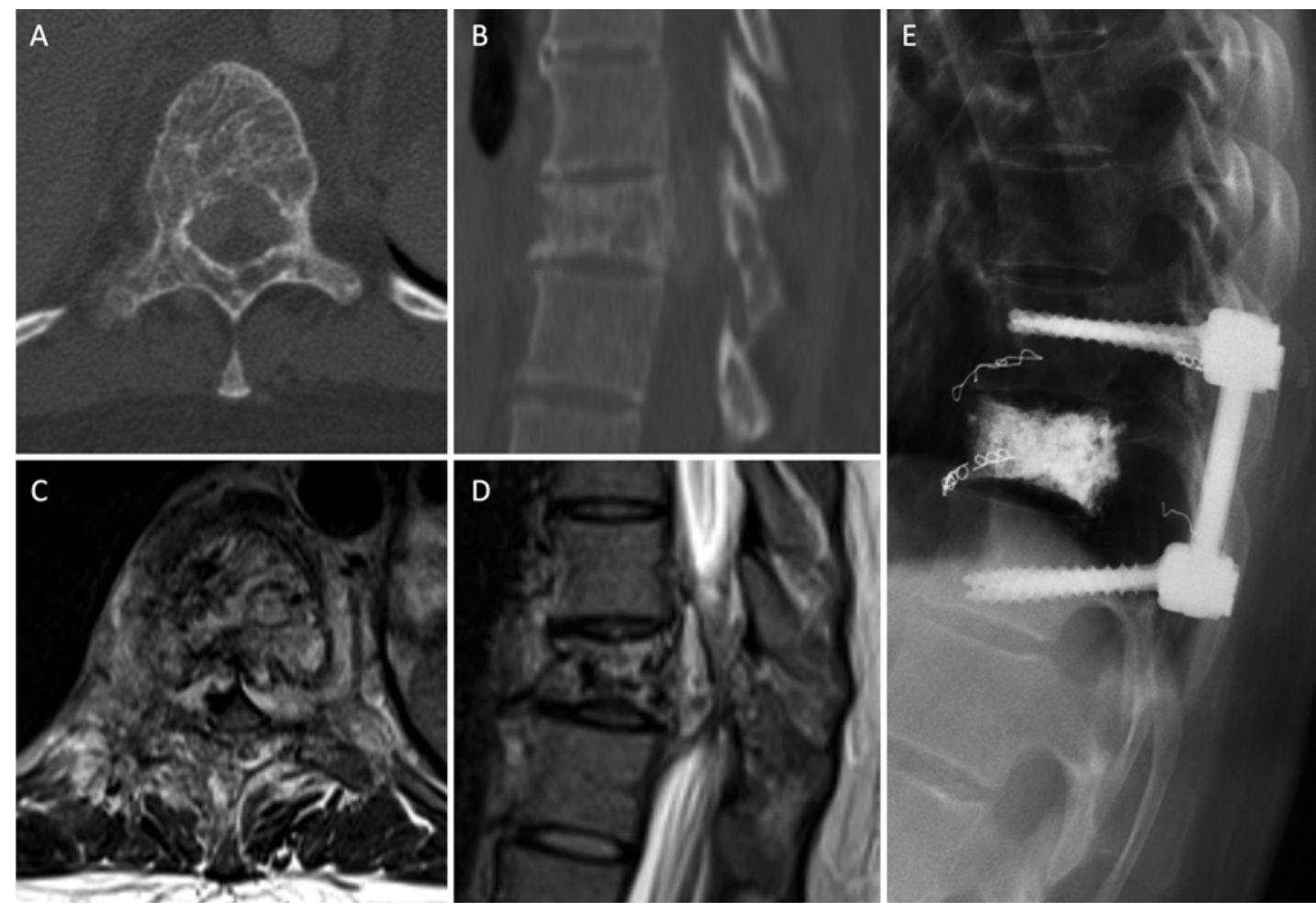

FIG. 1. Images obtained in Case 3, which involved a 30-year-old woman who presented with progressive postpartum back pain. $A$ and B: Axial (A) and sagittal (B) CT images demonstrating an extensive aggressive vertebral hemangioma involving the entire T-11 vertebra, including the transverse processes and spinous process. C and D: Axial (C) and sagittal (D) T2-weighted MR images demonstrating soft tissue extension of the tumor into the epidural space resulting in spinal cord compression. E: Postoperative lateral radiograph obtained after subtotal resection and vertebroplasty showing cement filling the residual vertebral body, which was involved in tumor. Coils from the preoperative embolization can also be seen here.

The patient was then taken to the operating room and turned prone on an open Jackson table. A semilunar incision was made, and a flap of skin, subcutaneous tissue, and fascia was rotated medially over the spinous processes. A right-sided periosteal exposure was then performed, revealing only the base of the spinous process, lamina, and facet joints from T-7 through T-9 while keeping the posterior longitudinal ligament and muscular attachments intact. A hemilaminectomy was then created from the inferior aspect of T-7 to the superior aspect of T-9. A medial facetectomy was performed at T7-8 and T8-9, and the medial portion of the T- 8 and T- -9 pedicles was removed with a high-speed drill. The T-8 nerve root was now exposed as it passed caudal to the pedicle, and it was ligated proximal to the dorsal root ganglion. At this point, the tumor was visible and was separated from the dura with a Penfield No. 4 dissector. Both a soft tissue and a bony component of the tumor were seen in the epidural space and tracking into the right T8-9 neural foramen. The soft tissue component was removed with a scalpel and a small pituitary rongeur. The bony component was subsequently removed with the drill. The tumor that remained in the foramen was removed with an angled curette. Using the drill followed by a series of straight and angled curettes the central portion of the hemangioma within the vertebral body was then removed. Because this required resection of a large portion of the vertebral body, intraoperative vertebroplasty was performed under fluoroscopic guidance to restore the anterior load-sharing capacity at that segment. Instrumentation was not required due to the preservation of the midline tension band and the facets. The wound was closed in layers.

Following surgery, the patient recovered to her neurological baseline. At her first follow-up appointment her symptoms were completely resolved and she reported only a small area of numbness in the distribution of the right T-8 nerve root, which had been sacrificed. At her most recent follow-up visit, 8 months after surgery, she continued to do well with no clinical or radiographic signs of recurrence.

\section{Discussion}

Vertebral hemangiomas were first reported by Virchow in 1863 and were first associated with neurological symptoms by Gerhardt in 1895. Later, in 1927, Makrykostas described how "ballooning" of the vertebrae or epidural extension of a vertebral hemangioma could result in spinal canal stenosis and neurological symptoms. ${ }^{52}$ Despite our long-standing recognition of aggressive vertebral hemangiomas, there is still controversy regarding the optimal treatment strategy, and numerous therapeutic options have been described (Tables 2-4).

\section{Radiation Therapy}

Radiation therapy was recognized as an effective strat- 

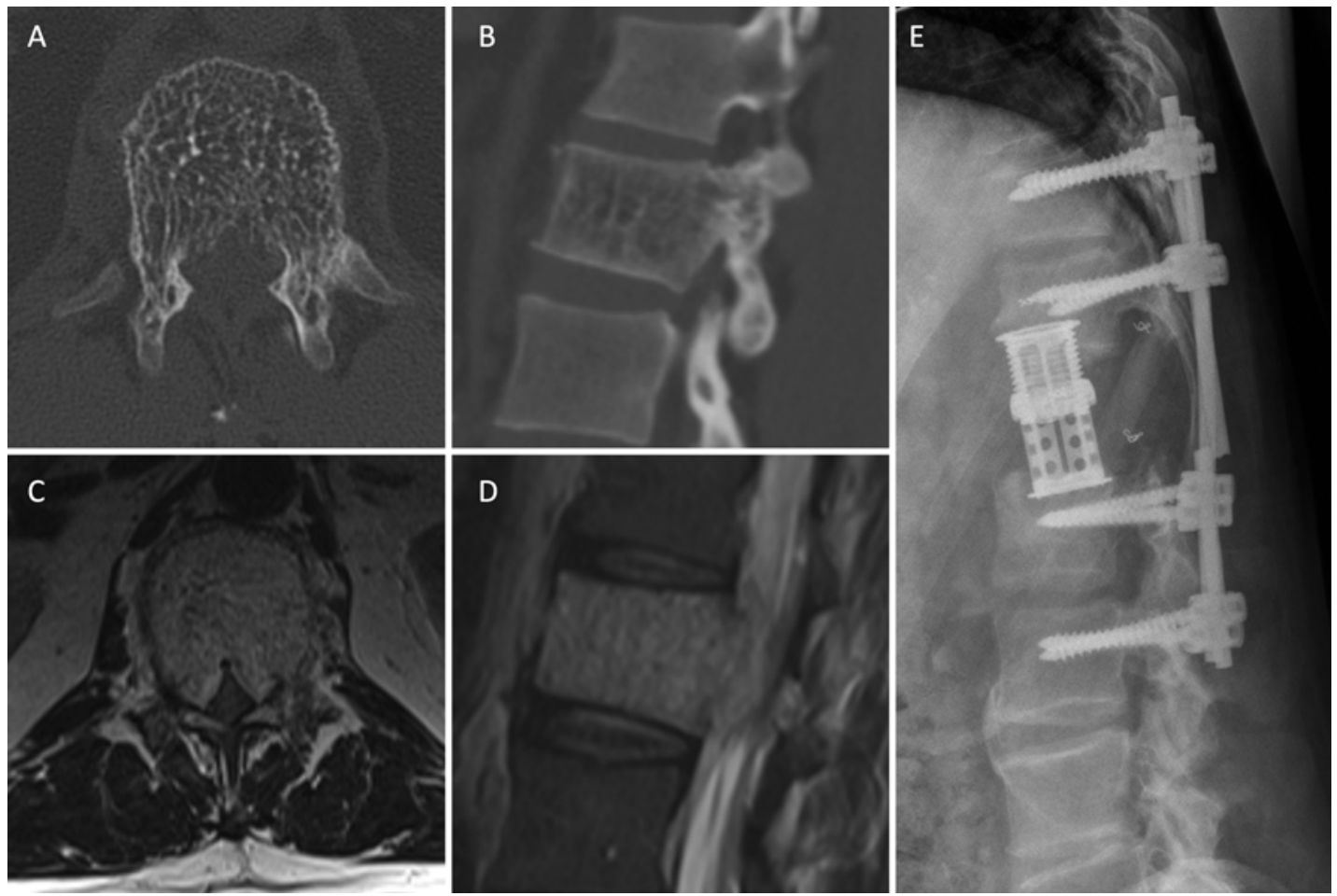

FIG. 2. Images obtained in Case 1, which involved a 48-year-old man who presented with back pain and radiculopathy. A and B: Axial (A) and sagittal (B) CT images demonstrating an aggressive vertebral hemangioma involving the entire vertebral body of L-1 and extending through both pedicles into the posterior elements. C and D: Axial (C) and sagittal (D) T2-weighted MR images showing additional epidural soft tissue extension within the spinal canal resulting in compression of the conus medullaris and cauda equina. The patient underwent en bloc resection requiring extensive spinal reconstruction. E: Lateral radiograph obtained 28 months after the initial surgery when the patient presented with severe back pain and was found to have a fractured rod.

egy for the treatment of aggressive vertebral hemangiomas by the 1930s. Since that time it has been recommended as a primary modality only for the treatment of slowly progressive lesions primarily because the therapeutic effects are delayed. ${ }^{19,32,45,52}$ In 1951, Manning ${ }^{52}$ described several cases in which radiation therapy resulted in complete resolution of symptoms and controlled local progression of disease. Glanzmann et al. ${ }^{30}$ described a series of 62 patients treated with radiation therapy between 1939 and 1975 and reported that $60 \%$ experienced permanent improvement. In 1985, Faria et al. ${ }^{24}$ described a series of 9 patients with symptomatic vertebral hemangiomas treated with radiation therapy and reported that $77 \%$ had complete or nearcomplete resolution of symptoms, including a woman who had presented with paraplegia during pregnancy. They also reported that no patient who initially responded to treatment experienced recurrence of disease. Yang et al. ${ }^{70}$ reported on 23 patients with aggressive hemangiomas who underwent radiation therapy and found that over $80 \%$ experienced relief of pain and sensory symptoms and 5 of 7 patients who presented with paraplegia regained the ability to walk. In another study of 17 cases in which patients were treated with radiation, $87.5 \%$ had complete resolution of pain, $66.7 \%$ of patients had complete resolution of numbness or paresis, and $66.6 \%$ of patients with paraplegia recovered completely. In this study the patients who did not recover had long-standing paraplegia and presumably irreversible spinal cord injury. ${ }^{6}$ In 2014 , Jiang et al. ${ }^{45}$ published a retrospective series of 29 consecutive patients with aggressive vertebral hemangiomas. In this series 10 patients with slowly progressive neurological deficits underwent radiation therapy alone, but the treatment failed in 2 cases, and those 2 patients required surgery.

A retrospective analysis of pooled data suggests that there is a dose-effect relationship for the treatment of symptomatic vertebral hemangiomas with radiation alone, and the authors recommended a total dose of $40 \mathrm{~Gy} .{ }^{58} \mathrm{In}$ 2010, Aich et al. ${ }^{3}$ treated 7 consecutive patients with aggressive vertebral hemangiomas with 40 Gy of external beam radiation therapy over 4 weeks and noted that all of the patients tolerated treatment well and demonstrated improvement in motor strength. At last follow up, 6 of 7 had either no weakness or mild weakness only. With the development of intensity-modulated radiation therapy, it may be possible to safely deliver higher doses of radiation while avoiding complications such as radiation myelopathy and pulmonary radionecrosis, but this has not been shown in patients with vertebral hemangiomas. ${ }^{3,16,62}$

It should be noted that the radiographic appearance of aggressive vertebral hemangiomas has not been reported to change after a number of years, even with successful treatment. ${ }^{24,52}$ This likely indicates that radiation is effective at controlling pathological vascular tissue but does not have a radiographically demonstrable effect on the surrounding bony tissue. For this reason authors have suggested that radiation alone may be less effective for 


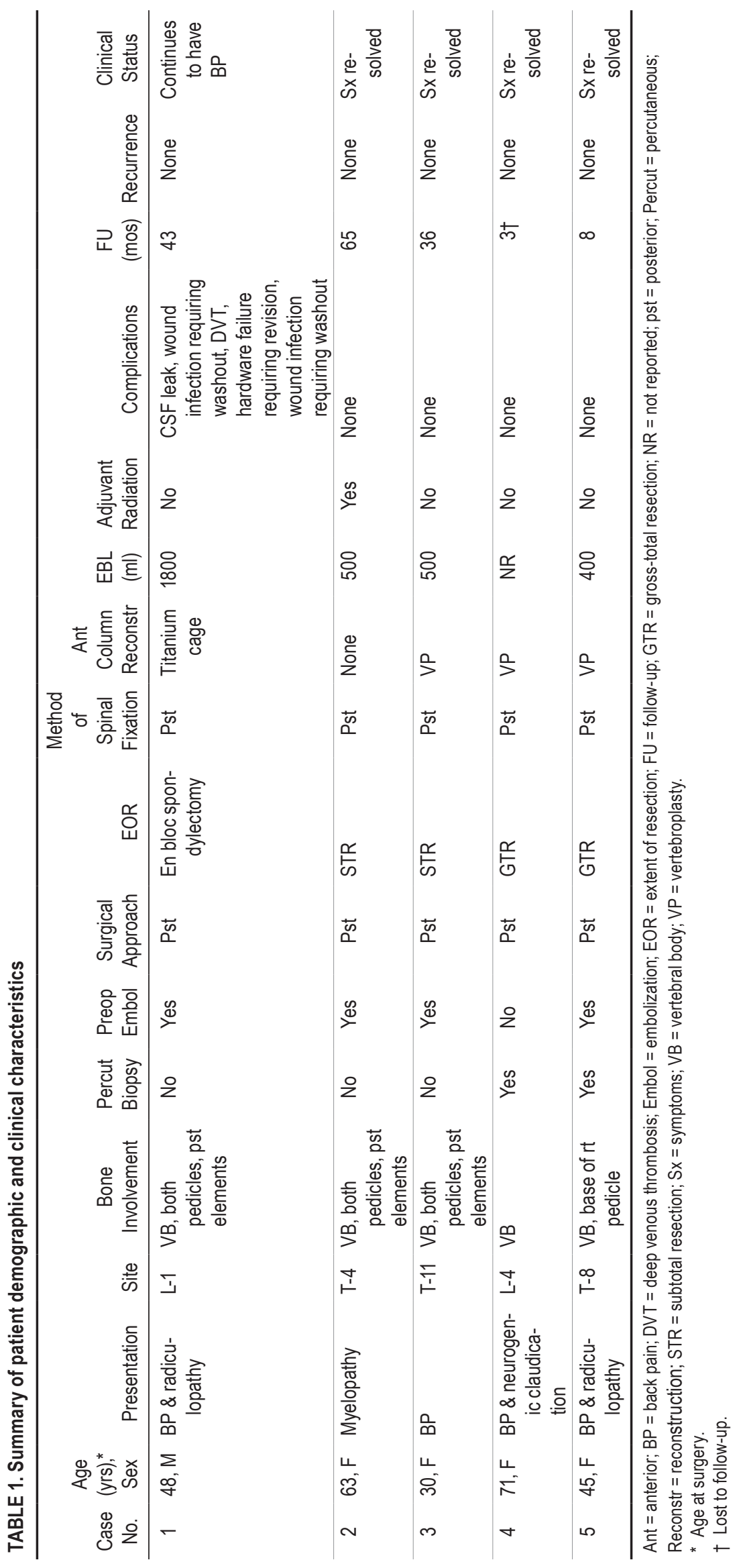

Neurosurg Focus Volume $41 \cdot$ August 2016 

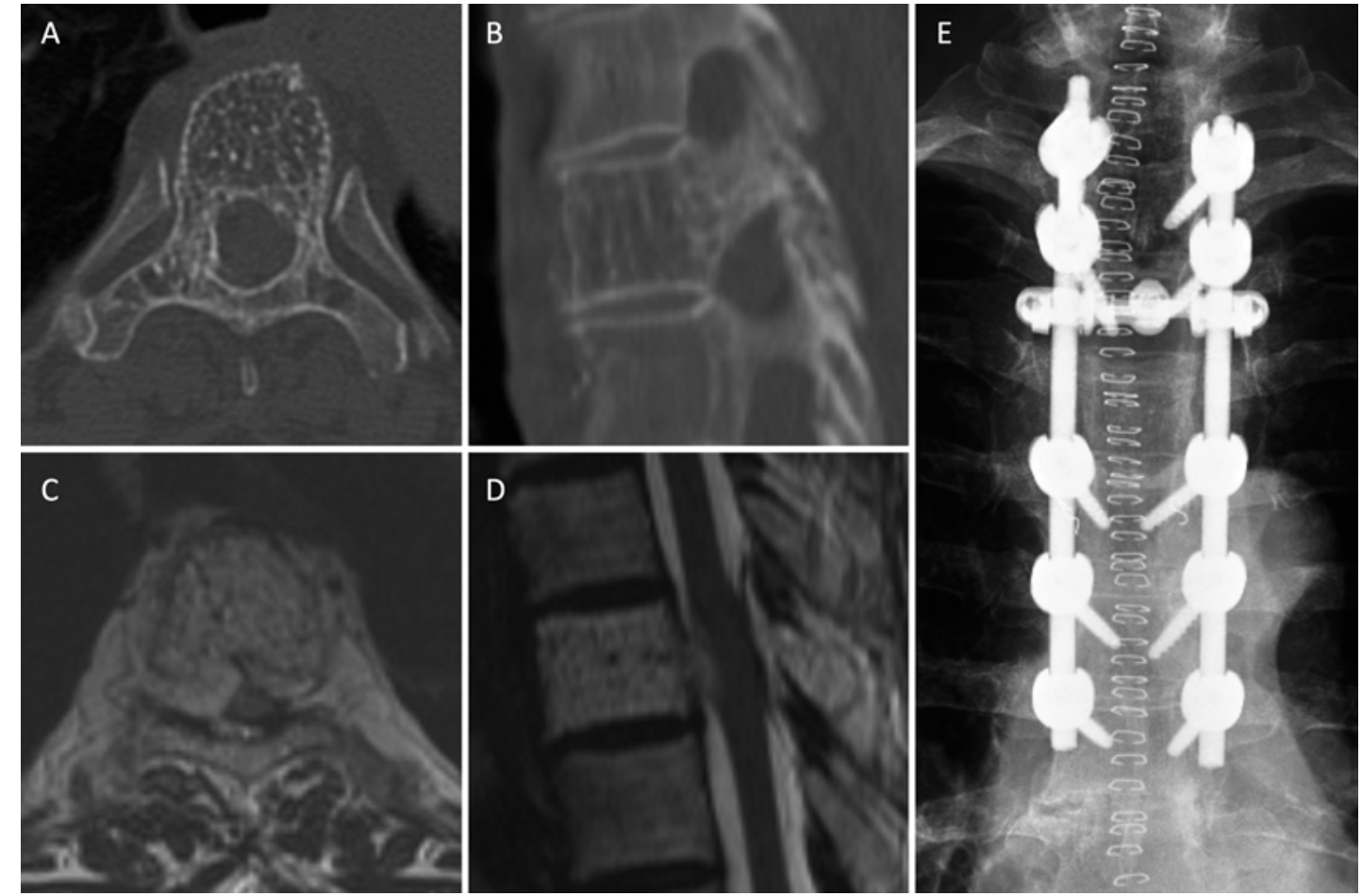

FIG. 3. Images obtained in Case 2, which involved a 63-year-old woman who presented with myelopathy. A: Axial CT image demonstrating an aggressive vertebral hemangioma at T-4 with a characteristic honeycomb pattern that expands the cortex and involves the entire vertebral body and both pedicles and extends into the posterior elements. B: Sagittal CT image showing a corduroy pattern characteristic of vertebral hemangiomas. C and D: Axial (C) and sagittal (D) T2-weighted MR images showing epidural spread of disease. This patient underwent a decompressive laminectomy and instrumented fusion for subtotal resection of the tumor followed by a course of radiation therapy. E: Postoperative anteroposterior radiograph.

patients who have neurological compression due to focal bone hypertrophy. ${ }^{16}$

\section{Vertebroplasty}

Vertebroplasty with methyl methacrylate cement has been described in the treatment of vertebral hemangiomas since the late $1980 \mathrm{~s} .^{74}$ This technique not only provides hemostatic embolization, but also improves the load-bearing capacity of the anterior column. Feydy et al..$^{25}$ reported 2 cases of painful cervical vertebral hemangiomas that were treated with vertebroplasty, resulting in immediate resolu-
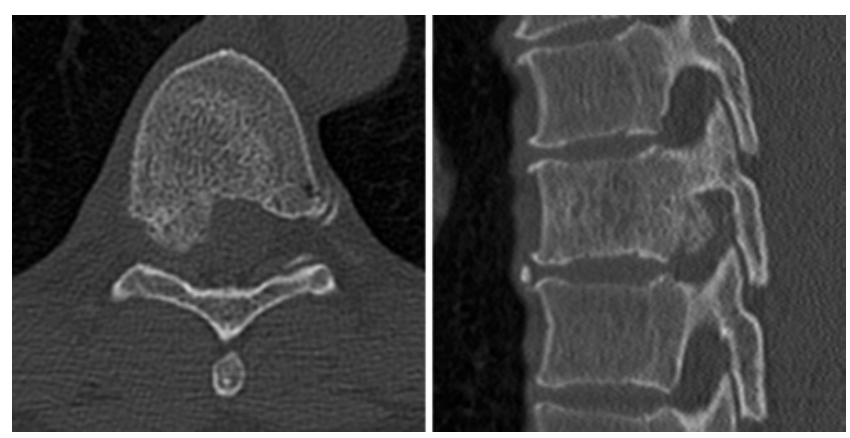

FIG. 4. Images obtained in Case 5 , which involved a 45-year-old woman who presented with right flank pain. Axial (left) and sagittal (right) CT images demonstrating irregular vertical trabeculae in the T-8 vertebral body as well as cortical expansion involving the posterior cortex and pedicle. tion of symptoms, but neither of these lesions had cortical expansion or epidural extension characteristic of aggressive vertebral hemangiomas. Some authors have recommended against the use of vertebroplasty alone in the treatment of aggressive hemangiomas as the cement may form a dense cast including the epidural portion of the cavity. ${ }^{1,32}$ Others have used vertebroplasty in these cases with success and have reported shrinkage of the epidural component due to decreased vascularity. ${ }^{34,45}$ One case in which vertebroplasty was used to treat an aggressive hemangioma with epidural disease was complicated by leaking of cement into the spinal canal. ${ }^{23}$ Guarnieri et al. ${ }^{34}$ published a series of 24 cases of vertebral hemangiomas including 6 with aggressive features and noted that none of the patients had recurrent symptoms at 4-year follow-up. Balloon kyphoplasty has been reported to decrease the risk of cement leakage. ${ }^{46,74}$ Either kyphoplasty or vertebroplasty may also be used intraoperatively in conjunction with decompressive surgery as we have done with several of our patients in the present series. ${ }^{41}$

\section{Ethanol Ablation}

Percutaneous ethanol ablation of aggressive vertebral hemangiomas was first described in 1994 by Heiss, Doppman, and Oldfield. ${ }^{38}$ A series of 14 patients with aggressive vertebral hemangiomas treated with percutaneous ethanol ablation showed that $93 \%$ of patients had an "excellent" or "good" clinical result within 14 months of 
TABLE 2. Selective review of key literature on radiation therapy for aggressive vertebral hemangiomas

\begin{tabular}{|c|c|c|c|c|}
\hline $\begin{array}{l}\text { Authors \& } \\
\text { Year }\end{array}$ & Study Design & $\begin{array}{l}\text { No. of } \\
\text { Pts }\end{array}$ & Results & Conclusions \\
\hline $\begin{array}{l}\text { Manning, } \\
1951\end{array}$ & Retrospective & 3 & $\begin{array}{l}\text { Clinical improvement in all } 3 \text { pts following RT w/ no } \\
\text { recurrence at } 4-10 \text { yrs FU }\end{array}$ & $\begin{array}{l}\mathrm{RT} \text { is acceptable as a primary Tx for symptomatic verte- } \\
\text { bral hemangiomas w/o sudden cord compression }\end{array}$ \\
\hline $\begin{array}{l}\text { Glanzmann } \\
\text { et al., } \\
1977\end{array}$ & Retrospective & 62 & $\begin{array}{l}\text { Permanent clinical improvement seen in } \sim 60 \% \text { of pts } \\
\text { following RT }\end{array}$ & $\begin{array}{l}\text { Radiation may be used to treat symptomatic hemangio- } \\
\text { mas. In pts w/ severe cord compression, decompres- } \\
\text { sive surgery should precede RT }\end{array}$ \\
\hline $\begin{array}{l}\text { Faria et al., } \\
\quad 1985\end{array}$ & Retrospective & 9 & $\begin{array}{l}77 \% \text { had complete/near-complete resolution of Sx } \\
\text { following RT w/ 6-44 mos FU \& no complications }\end{array}$ & $\begin{array}{l}\mathrm{RT} \text { is safe \& effective for Tx of symptomatic vertebral } \\
\text { hemangiomas }\end{array}$ \\
\hline $\begin{array}{l}\text { Yang et al., } \\
\quad 1985\end{array}$ & Retrospective & 23 & $\begin{array}{l}88 \% \text { experienced relief of } \mathrm{BP}, 80 \% \text { experienced relief } \\
\text { of numbness, } 5 \text { of } 7 \text { paraplegic pts regained ability } \\
\text { to ambulate }\end{array}$ & $\begin{array}{l}\text { Even w/ severe spinal cord compression, radiation can } \\
\text { be used as primary Tx }\end{array}$ \\
\hline $\begin{array}{l}\text { Asthana et } \\
\text { al., } 1990\end{array}$ & Retrospective & 17 & $\begin{array}{l}\text { 87.5\% experienced complete relief of pain/tender- } \\
\text { ness, } 66.7 \% \text { experienced complete relief of numb- } \\
\text { ness, } 6 \text { of } 9 \text { paraplegic pts recovered completely, } \\
\& 2 \text { had no response }\end{array}$ & $\begin{array}{l}\text { Symptomatic vertebral hemangiomas can be treated w/ } \\
\text { radiation. Radiation may be used as primary } \mathrm{Tx}\end{array}$ \\
\hline $\begin{array}{l}\text { Aich et al., } \\
2010\end{array}$ & Retrospective & 7 & $\begin{array}{l}100 \% \text { showed improvement in strength, pain relief, \& } \\
\text { increased quality of life }\end{array}$ & $\mathrm{RT}$ is dose dependent \\
\hline $\begin{array}{l}\text { Jiang et al., } \\
\quad 2014\end{array}$ & Retrospective & 29 & $\begin{array}{l}\text { In } 2 \text { of } 10 \text { pts who underwent RT alone, Tx failed \& } \\
\text { surgery was required. No recurrences were seen } \\
\text { following RT, average FU } 51.1 \text { mos }\end{array}$ & $\begin{array}{l}\text { RT may be useful as a stand-alone Tx in pts w/ mild or } \\
\text { slowly progressive neurological deficits }\end{array}$ \\
\hline
\end{tabular}

Pts = patients; $\mathrm{RT}=$ radiation therapy; $\mathrm{Tx}=$ treatment.

the procedure. ${ }^{32}$ Another series of 11 patients with aggressive vertebral hemangiomas treated with ethanol injection showed complete obliteration of the lesions on postprocedure angiography and no recurrence at follow-up of 15-76 months. ${ }^{17}$ Although this treatment strategy has been effective in ameliorating neurological symptoms, there is little long-term data on the rate of recurrence and numerous complications have been reported, including osteonecrosis, vertebral collapse, transient neurological deterioration, spinal cord injury, hemodynamic instability, and asystole. ${ }^{17,32,38,55,63,69}$ To avoid the risk of vertebral collapse, some surgeons may inject lower doses of ethanol or combine ethanol injection with percutaneous vertebroplasty..$^{13,17} \mathrm{~A}$ case report by Chen et al. ${ }^{10}$ also describes the successful treatment of an aggressive vertebral hemangioma using ethanol injection in combination with en- dovascular embolization with no clinical or radiographic recurrence at 21-month follow-up. Nevertheless, because there are other treatment options with comparable clinical outcomes and fewer complications, alcohol ablation has fallen out of favor.

\section{Endovascular Embolization}

Vertebral hemangiomas are highly vascular lesions and one of the greatest risks of surgical intervention is uncontrollable hemorrhage.,4,6,19 In 1951, without the benefit of modern surgical technology, Manning estimated the operative mortality rate associated with resection of a vertebral hemangioma to be $20 \%-25 \%$ due to uncontrollable bleeding. ${ }^{52}$ In the 1970 s it was suggested that angiography could be used not only to confirm the diagnosis but also to

TABLE 3. Selective review of key literature on embolization for aggressive vertebral hemangiomas

\begin{tabular}{|c|c|c|c|c|}
\hline Authors \& Year & Study Design & $\begin{array}{l}\text { No. of } \\
\text { Pts }\end{array}$ & Results & Conclusions \\
\hline $\begin{array}{l}\text { Gross et al., } \\
\quad 1976\end{array}$ & Retrospective & 1 & $\begin{array}{l}\text { Neurological improvement w/in } 48 \text { hrs following } \\
\text { endovascular embol w/ Gelfoam }\end{array}$ & $\begin{array}{l}\text { Therapeutic embol should be considered in pts w/ } \\
\text { aggressive hemangiomas }\end{array}$ \\
\hline $\begin{array}{l}\text { Hekster \& Endtz, } \\
\quad 1987\end{array}$ & Retrospective & 1 & $\begin{array}{l}\text { Paraplegic pt treated w/ embol followed by RT was } \\
\text { in excellent clinical condition } 7 \text { mos later; pt } \\
\text { remained in excellent condition at 15-yr FU }\end{array}$ & $\begin{array}{l}\text { Endovascular embol may result in good long-term } \\
\text { control when used in combination w/ RT }\end{array}$ \\
\hline Raco et al., 1990 & Retrospective & 5 & $\begin{array}{l}2 \text { of } 5 \text { pts treated w/ embol experienced clinical } \\
\text { improvement \& did not require further Tx }\end{array}$ & $\begin{array}{l}\text { Embolization alone is adequate for treatment of } \\
\text { some symptomatic vertebral hemangiomas }\end{array}$ \\
\hline Smith et al., 1993 & Retrospective & 8 & No pt improved w/ embol alone & Embolization may not be useful as a stand-alone $\mathrm{Tx}$ \\
\hline $\begin{array}{l}\text { Kiroglu et al., } \\
2009\end{array}$ & Retrospective & 1 & $\begin{array}{l}\text { Pt w/ pain \& paraplegia underwent endovascular } \\
\text { embol \& } 2 \text { yrs later had recurrent spinal cord } \\
\text { compression \& required surgical Tx }\end{array}$ & $\begin{array}{l}\text { Aggressive vertebral hemangiomas may recur after } \\
\text { embol alone }\end{array}$ \\
\hline
\end{tabular}


TABLE 4. Selective review of key literature on surgery for aggressive vertebral hemangiomas

\begin{tabular}{|c|c|c|c|c|}
\hline $\begin{array}{l}\text { Authors \& } \\
\quad \text { Year }\end{array}$ & Study Design & $\begin{array}{c}\text { No. } \\
\text { of } \\
\text { Pts }\end{array}$ & Results & Conclusions \\
\hline $\begin{array}{l}\text { Djindjian } \\
\text { et al., } \\
1992\end{array}$ & Retrospective & 1 & $\begin{array}{l}\text { Pt w/ multiple aggressive vertebral hemangiomas treated w/ } \\
\text { embol, laminectomy, RT \& was subsequently asympto- } \\
\text { matic for } 6 \text { yrs }\end{array}$ & $\begin{array}{l}\text { Embolization, laminectomy, and RT may be used } \\
\text { in cases in which total resection is not possible }\end{array}$ \\
\hline $\begin{array}{l}\text { Fox \& } \\
\text { Onofrio, } \\
1993\end{array}$ & Retrospective & 11 & $\begin{array}{l}\text { Series included } 11 \text { pts w/ aggressive vertebral hemangio- } \\
\text { mas who underwent surgery. Of } 5 \text { pts who underwent } \\
\text { STR w/o adjuvant RT, } 2 \text { developed recurrence. Of } 5 \text { pts } \\
\text { who underwent STR w/ RT, } 1 \text { developed recurrence, but } \\
\text { that pt may have received an ineffective dose of radiation }\end{array}$ & $\begin{array}{l}\text { Patients w/ progressive neurological deficit should } \\
\text { undergo preop embol \& surgery. When STR is } \\
\text { performed, adjuvant RT should be used }\end{array}$ \\
\hline $\begin{array}{l}\text { Bremnes } \\
\text { et al., } \\
1996\end{array}$ & Retrospective & 1 & $\begin{array}{l}\text { Pt who presented w/ paraparesis was treated w laminec- } \\
\text { tomy, subtotal decompression, \& RT and was neurologi- } \\
\text { cally normal } 2 \text { yrs after surgery }\end{array}$ & $\begin{array}{l}\text { There is a beneficial role for RT in combination w/ } \\
\text { surgical decompression }\end{array}$ \\
\hline $\begin{array}{l}\text { Jayakumar } \\
\text { et al., } \\
1997\end{array}$ & Retrospective & 12 & $\begin{array}{l}\text { Pts were treated w/ embol, laminectomy, \& RT; } 11 \text { of } 12 \text { pts } \\
\text { were clinically improved but } 1 \text { pt was Frankel Grade A \& } \\
\text { remained unchanged }\end{array}$ & $\begin{array}{l}\text { Preop embol should be routine, } \& \text { when it is used } \\
\text { in combination w/ laminectomy \& radiation, } \\
\text { most pts have favorable outcomes }\end{array}$ \\
\hline $\begin{array}{l}\text { Inoue et } \\
\quad \text { al., } 2007\end{array}$ & Retrospective & 1 & $\begin{array}{l}\text { Case report of hemangioma removed en bloc. The pt was } \\
\text { asymptomatic w/o evidence of recurrence at 4-yr FU }\end{array}$ & $\begin{array}{l}\text { En bloc resection is a treatment option for aggres- } \\
\text { sive vertebral hemangiomas }\end{array}$ \\
\hline $\begin{array}{l}\text { Kato et al., } \\
\quad 2010\end{array}$ & Retrospective & 5 & $\begin{array}{l}2 \text { pts underwent en bloc resection; } 2 \text {, intralesional resection; } \\
1 \text {, piecemeal resection. The pt who underwent piecemeal } \\
\text { resection had the highest operative blood loss }\end{array}$ & $\begin{array}{l}\text { En bloc resection may be associated w/ less blood } \\
\text { loss than piecemeal resection }\end{array}$ \\
\hline $\begin{array}{l}\text { Acosta et } \\
\quad \text { al., } 2011\end{array}$ & Retrospective & 10 & $\begin{array}{l}\text { Pts treated w/ preop embol followed by intralesional spon- } \\
\text { dylectomy had improvement in BP VAS score. No pt had } \\
\text { recurrence or required further therapy }\end{array}$ & $\begin{array}{l}\text { GTR results in clinical improvement \& good long- } \\
\text { term control }\end{array}$ \\
\hline $\begin{array}{l}\text { Urrutia et } \\
\quad \text { al., } 2011\end{array}$ & Retrospective & 4 & $\begin{array}{l}\text { Pts treated w/ preop embol \& resection. At FU (mean } 53 \\
\text { mos) only } 1 \text { pt had recurrence }\end{array}$ & $\begin{array}{l}\text { Total resection or STR w/ RT may be used in treat- } \\
\text { ment of aggressive vertebral hemangiomas }\end{array}$ \\
\hline $\begin{array}{l}\text { Jiang et al., } \\
\quad 2014\end{array}$ & Retrospective & 29 & $\begin{array}{l}21 \text { pts underwent surgery for aggressive vertebral heman- } \\
\text { giomas; } 6 \text { pts did not receive RT, \& of those, } 3 \text { developed } \\
\text { recurrence. There were no recurrences in pts who } \\
\text { received RT or who had GTR }\end{array}$ & $\begin{array}{l}\text { RT should be used after subtotal resection, except } \\
\text { in cases where the tumor is obliterated by } \\
\text { vertebroplasty cement }\end{array}$ \\
\hline $\begin{array}{l}\text { Goldstein } \\
\text { et al., } \\
2015\end{array}$ & $\begin{array}{l}\text { Prospective/ } \\
\text { retrospective }\end{array}$ & 68 & $\begin{array}{l}\text { In } 68 \text { pts w/ symptomatic vertebral hemangiomas, recur- } \\
\text { rence rate was } 3 \%\end{array}$ & $\begin{array}{l}\text { Surgery results in excellent local control of symp- } \\
\text { tomatic vertebral hemangiomas. En bloc resec- } \\
\text { tion is not required for good clinical outcomes }\end{array}$ \\
\hline
\end{tabular}

VAS = visual analog scale.

perform endovascular embolization of the feeding arteries in order to reduce vascularity of the tumor and decrease blood loss during surgery. $8,19,22,37,50,53,59,73$ The benefits of embolization were confirmed in a systematic review that included 51 patients with aggressive vertebral hemangiomas. This study found that in the group that received preoperative embolization, blood loss was significantly less than in the group that did not (980 vs $1629 \mathrm{ml}$, respectively).$^{60}$ Cotten et al. ${ }^{15}$ reported that preoperative embolization can be used in combination with vertebroplasty to even further reduce blood loss during surgery.

Endovascular embolization has also been proposed as a definitive treatment for aggressive vertebral hemangiomas without surgery. $7,33,39,57$ Gross et al..$^{33}$ describe a case involving a patient who had a high-grade spinal block due to a vertebral hemangioma that was relieved following endovascular embolization with Gelfoam. Hekster and Endtz ${ }^{39}$ treated a patient with an aggressive vertebral hemangioma causing paraplegia with embolization followed by radiotherapy and found that the patient had an excellent clinical outcome with no recurrence at 15 years. Raco et al. ${ }^{57}$ reported on 2 patients who underwent embolization alone, both of whom had clinical improvement and remained free from recurrence at 18 and 36 months following the procedure.

Other authors have reported more negative experiences, however. Kiroglu et al. ${ }^{48}$ published a case report describing a woman who developed symptoms from an aggressive vertebral hemangioma during pregnancy and was initially treated with embolization but developed recurrent spinal cord compression 2 years later. Likewise, in a retrospective review of 8 patients, Smith et al. ${ }^{65}$ did not find that any of their patients experienced improvement with embolization alone. Embolization is also generally contraindicated when feeding vessels supply the artery of Adamkiewicz as well as the hemangioma; in addition, surgeons must be cautious of reflux of the embolic material into the intercostal or lumbar arteries. ${ }^{16,32}$ As an alternative, transpedicular embolization with NBCA has been described, and this may be useful when transarterial embolization is unsafe..$^{28,71}$

\section{Surgery}

Surgical decompression and gross-total resection are 
commonly performed in the treatment of aggressive vertebral hemangiomas. Acosta et al. ${ }^{2}$ performed a retrospective review of 10 cases involving patients who underwent gross-total resection of aggressive vertebral hemangiomas with preoperative embolization followed by intralesional spondylectomy. They reported no recurrence at an average follow-up of 2.42 years and concluded that gross-total resection decreased the likelihood of recurrence without the need for radiation therapy. Another retrospective review described 4 patients who were treated with preoperative embolization followed by either decompressive laminectomy and fusion or an anterior corpectomy for gross-total resection. In this study, 1 patient had a subtotal resection without adjuvant radiation therapy and later developed recurrence at 15 months. The other 3 patients, however, had no recurrent disease at $45-72$ months. ${ }^{68}$ Goldstein et al. ${ }^{31}$ recently described a large multicenter cohort of 68 patients with symptomatic vertebral hemangiomas treated with surgery and reported a local recurrence rate of $3 \%$. In this series, 7 patients with aggressive vertebral hemangiomas underwent en bloc resection with no recurrence of tumor. Because of conflicting data in the article it is not clear how many patients with aggressive vertebral hemangiomas underwent intralesional resection-which in this study could mean either subtotal or gross-total resection-but there was at least 1 patient who had an intralesional resection without radiation therapy and developed a recurrence (at 5.3 years after surgery).

Many authors have recommended surgery followed by adjuvant radiation therapy. Jayakumar et al. ${ }^{43}$ published a case series involving 12 patients with spinal cord compression from aggressive vertebral hemangiomas who were treated with preoperative embolization, decompressive laminectomy for subtotal resection, and adjuvant radiation therapy. Eleven of the 12 patients had favorable clinical outcomes, but long-term follow-up data on recurrence were not provided. Djindjian et al. ${ }^{16}$ presented a similar case involving a man with an aggressive vertebral hemangioma treated with embolization, decompressive surgery, and postoperative radiation who had complete resolution of his symptoms and no recurrence within 6 years. Bremnes et al..$^{9}$ described yet another case involving a patient with an aggressive vertebral hemangioma who did well with decompressive laminectomy and subtotal tumor excision followed by radiation. In 1993, Fox and Onofrio ${ }^{26}$ published a study including 10 patients with aggressive vertebral hemangiomas resulting in spinal cord compression who underwent subtotal resection and 1 patient who underwent gross-total resection. Two of 5 patients who underwent subtotal resection without adjuvant radiation developed recurrence at 5-6 years postoperatively. One of 5 patients who underwent subtotal resection with adjuvant radiation developed a recurrence 17 years postoperatively, but this patient only received $10 \mathrm{~Gy}$ radiation, whereas the other 4 patients without recurrence received between 26 and 45 Gy. Several studies discussed above suggest that 10 Gy is an ineffective dose, and this may be the reason for the late recurrence. ${ }^{3,40,58}$ The remaining patient had grosstotal resection without adjuvant radiation therapy and did not have recurrence of disease. ${ }^{26}$ In the retrospective series by Jiang et al., ${ }^{45} 21$ cases involving patients with severe or quickly evolving neurological deficits underwent surgery for aggressive vertebral hemangiomas, including 2 patients who had surgery after failure of radiation therapy. Most patients underwent preoperative embolization followed by decompressive surgery or subtotal resection, sometimes in combination with vertebroplasty. The authors found that 3 of the 6 patients who underwent decompression without radiation therapy developed recurrence 12-108 months postoperatively. None of the patients who had a total resection or were treated with a combination of radiation and surgery had any recurrence at 24-133 months' follow-up.

Within the last 10 years there have been occasional reports of en bloc resection of aggressive vertebral hemangiomas in the literature. En bloc tumor removal is technically challenging and is associated with a high rate of morbidity. One systematic review reported a $36.3 \%$ complication rate for en bloc resection spinal tumors. ${ }^{14}$ Another study reported higher rates of revision for patients who had en bloc resection when compared with those who had piecemeal resection of spinal tumors. ${ }^{20}$ As a result, this operation is generally reserved for patients with a pathological diagnosis such as chordoma or chondrosarcoma for which there is a proven survival benefit.

In 2007, Inoue et al. ${ }^{42}$ reported performing an en bloc spondylectomy for removal of an aggressive vertebral hemangioma involving the vertebral body, pedicle, and lamina of L-2. When the decision to perform an en bloc resection was made, the authors had obtained a nondiagnostic biopsy and believed the tumor was a more ominous primary spinal column tumor, evidence that would suggest it should be removed en bloc. However the postoperative pathology revealed an aggressive vertebral hemangioma. The authors acknowledge that, had they known the correct pathological diagnosis, they would have performed only a percutaneous vertebroplasty instead. Although they reported that the patient did well following surgery, the operation itself required an anterior and posterior approach, took over 9 hours, and involved $4000 \mathrm{ml}$ of blood loss even with preoperative embolization. Kato et al. ${ }^{47}$ performed a retrospective review of 5 cases involving patients with aggressive vertebral hemangiomas treated with preoperative embolization followed by total excision. Two patients underwent en bloc excision, 2 patients underwent a combination of en bloc and piecemeal excision, and the remaining patient underwent piecemeal excision. Regardless of surgical approach, all patients remained free of recurrence at 92-163 months of follow-up. Despite the lack of oncological benefit, the authors recommended en bloc excision as the treatment of choice because the single patient who underwent piecemeal resection had increased blood loss when compared with the patients who underwent en bloc resection (3400 $\mathrm{ml}$ vs an average of $2300 \mathrm{ml}$ ). Other reports of en bloc resection of hemangiomas have been published in the literature within the last few years. Although they do not report any complications from surgery or recurrence of tumor, they do not demonstrate superiority of en bloc surgery to piecemeal gross-total resection. ${ }^{31,35,56,66}$

\section{Institutional Experience}

In our series of 5 cases, regardless of the surgical strategy-subtotal resection, gross-total resection, or en bloc resection-none of the patients had developed recurrent disease at average follow-up of 31 months. Although the 2 
patients who underwent subtotal resection both had definite tumor left behind at the time of surgery, they each received either vertebroplasty or adjuvant radiation therapy to obliterate the remaining tumor, so we considered these lesions to be fully treated. Our experience suggests that there is only a low likelihood of recurrence for aggressive vertebral hemangiomas, and this has been confirmed throughout the existing literature. The patient who had the worst outcome and the most difficult treatment course was the patient who underwent en bloc resection and had multiple complications requiring several further surgeries. Although this is only one case, it is known from other tumor pathologies that en bloc resection is a highly morbid operation and that gross-total resection or subtotal resection with vertebroplasty or adjuvant radiation might provide similar control of the tumor with much lower morbidity.

\section{Conclusions}

Treatment of aggressive vertebral hemangiomas has been controversial in neurosurgery for over a century. Multiple therapeutic options have been described with varying degrees of success, including radiation, vertebroplasty, ethanol injection, embolization, surgery, and any combination thereof. The technical approach to surgery has also been debated, with some authors recommending decompression alone, others supporting gross-total resection, and still others who have recommended en bloc resection. Because aggressive vertebral hemangiomas are uncommon lesions, there are no large studies that directly compare treatment modalities, and there is therefore no strong evidence to support one particular therapeutic algorithm.

Despite this, based on our own experience and a careful review of the literature we feel that certain principles should still be followed. For patients with an uncertain radiological diagnosis, percutaneous biopsy should be performed to rule out lesions that can mimic an aggressive hemangioma. ${ }^{29,36,45,49}$ For patients with aggressive vertebral hemangiomas who present with mild or slowly progressive neurological symptoms, it is reasonable to attempt nonoperative management with embolization, vertebroplasty, or radiation therapy provided the symptoms are not due to compression by a focal bony prominence, which is unlikely to resolve without surgery. For patients with severe or rapidly progressive symptoms, surgery should be considered, with preoperative embolization when possible. Piecemeal gross-total resection and en bloc resection both seem to have good clinical outcomes with a low likelihood of tumor recurrence, but piecemeal gross-total resection is preferable due to lower rates of complication and reoperation. If it is only possible to perform a decompression or subtotal resection, vertebroplasty or adjuvant radiation therapy should be considered to reduce the risk of recurrence. Aggressive vertebral hemangiomas are benign lesions that do not have metastatic potential and are not associated with mortality. ${ }^{31}$ So even if a tumor recurs after subtotal resection, a second decompressive surgery may still be performed with a low risk of morbidity. ${ }^{1}$

\section{References}

1. Acosta FL Jr, Dowd CF, Chin C, Tihan T, Ames CP, Wein- stein PR: Current treatment strategies and outcomes in the management of symptomatic vertebral hemangiomas. Neurosurgery 58:287-295, 2006

2. Acosta FL Jr, Sanai N, Cloyd J, Deviren V, Chou D, Ames CP: Treatment of Enneking stage 3 aggressive vertebral hemangiomas with intralesional spondylectomy: report of 10 cases and review of the literature. J Spinal Disord Tech 24:268-275, 2011

3. Aich RK, Deb AR, Banerjee A, Karim R, Gupta P: Symptomatic vertebral hemangioma: treatment with radiotherapy. J Cancer Res Ther 6:199-203, 2010

4. Alexander J, Meir A, Vrodos N, Yau YH: Vertebral hemangioma: an important differential in the evaluation of locally aggressive spinal lesions. Spine (Phila Pa 1976) 35:E917E920, 2010

5. Arbajian E, Magnusson L, Brosjö O, Wejde J, Folpe AL, Nord KH, et al: A benign vascular tumor with a new fusion gene: EWSR1-NFATC1 in hemangioma of the bone. Am J Surg Pathol 37:613-616, 2013

6. Asthana AK, Tandon SC, Pant GC, Srivastava A, Pradhan S: Radiation therapy for symptomatic vertebral haemangioma. Clin Oncol (R Coll Radiol) 2:159-162, 1990

7. Asumu TO, Williamson B, Hughes DG: Symptomatic spinal hemangiomas in association with cutaneous hemangiomas. A case report. Spine (Phila Pa 1976) 21:1082-1084, 1996

8. Baker ND, Klein MJ, Greenspan A, Neuwirth M: Symptomatic vertebral hemangiomas: a report of four cases. Skeletal Radiol 15:458-463, 1986

9. Bremnes RM, Hauge HN, Sagsveen R: Radiotherapy in the treatment of symptomatic vertebral hemangiomas: technical case report. Neurosurgery 39:1054-1058, 1996

10. Chen HI, Heuer GG, Zaghloul K, Simon SL, Weigele JB, Grady MS: Lumbar vertebral hemangioma presenting with the acute onset of neurological symptoms. Case report. J Neurosurg Spine 7:80-85, 2007

11. Cheung NK, Doorenbosch X, Christie JG: Rapid onset aggressive vertebral haemangioma. Childs Nerv Syst 27:469472, 2011

12. Chi JH, Manley GT, Chou D: Pregnancy-related vertebral hemangioma. Case report, review of the literature, and management algorithm. Neurosurg Focus 19(3):E7, 2005

13. Cianfoni A, Massari F, Dani G, Lena JR, Rumboldt Z, Vandergrift WA, et al: Percutaneous ethanol embolization and cement augmentation of aggressive vertebral hemangiomas at two adjacent vertebral levels. J Neuroradiol 41:269-274, 2014

14. Cloyd JM, Acosta FL Jr, Polley MY, Ames CP: En bloc resection for primary and metastatic tumors of the spine: a systematic review of the literature. Neurosurgery 67:435-445, 2010

15. Cotten A, Deramond H, Cortet B, Lejeune JP, Leclerc X, Chastanet $\mathrm{P}$, et al: Preoperative percutaneous injection of methyl methacrylate and N-butyl cyanoacrylate in vertebral hemangiomas. AJNR Am J Neuroradiol 17:137-142, 1996

16. Djindjian M, Nguyen JP, Gaston A, Pavlovitch JM, Poirier J, Awad IA: Multiple vertebral hemangiomas with neurological signs. Case report. J Neurosurg 76:1025-1028, 1992

17. Doppman JL, Oldfield EH, Heiss JD: Symptomatic vertebral hemangiomas: treatment by means of direct intralesional injection of ethanol. Radiology 214:341-348, 2000

18. Duprez T, Lokietek W, Clapuyt P, DeMerlier Y, Malghem J, Gadisseux JF: Multiple aggressive vertebral haemangiomas in an adolescent: a case report. Pediatr Radiol 28:51-53, 1998

19. Eisenstein S, Spiro F, Browde S, Allen CM, Grobler L: The treatment of a symptomatic vertebral hemangioma by radiotherapy. A case report. Spine (Phila Pa 1976) 11:640-642, 1986

20. Elder BD, Sankey EW, Goodwin CR, Kosztowski TA, Lo SF, 
Bydon A, et al: Surgical outcomes in patients with high spinal instability neoplasm score secondary to spinal giant cell tumors. Global Spine J 6:21-28, 2016

21. Enneking WF: A system of staging musculoskeletal neoplasms. Clin Orthop Relat Res (204):9-24, 1986

22. Esparza J, Castro S, Portillo JM, Roger R: Vertebral hemangiomas: spinal angiography and preoperative embolization. Surg Neurol 10:171-173, 1978

23. Evangelopoulos DS, Kontovazenitis P, Kokkinis K, Glynos M, Korres DS, Sapkas G: Cement leakage in a symptomatic vertebral hemangioma: a case report and review of the literature. Cases J 2:7148, 2009

24. Faria SL, Schlupp WR, Chiminazzo H Jr: Radiotherapy in the treatment of vertebral hemangiomas. Int J Radiat Oncol Biol Phys 11:387-390, 1985

25. Feydy A, Cognard C, Miaux Y, Sola Martínez MT, Weill A, Rose M, et al: Acrylic vertebroplasty in symptomatic cervical vertebral haemangiomas: report of 2 cases. Neuroradiology 38:389-391, 1996

26. Fox MW, Onofrio BM: The natural history and management of symptomatic and asymptomatic vertebral hemangiomas. J Neurosurg 78:36-45, 1993

27. Friedman DP: Symptomatic vertebral hemangiomas: MR findings. AJR Am J Roentgenol 167:359-364, 1996

28. Garzon-Muvdi T, Iyer R, Goodwin CR, Abu-Bonsrah N, Orru E, Gailloud P, et al: Percutaneous embolization and spondylectomy of an aggressive L2 hemangioma. Spine J 16:e167e168, 2016

29. Gaudino S, Martucci M, Colantonio R, Lozupone E, Visconti E, Leone A, et al: A systematic approach to vertebral hemangioma. Skeletal Radiol 44:25-36, 2015

30. Glanzmann C, Rust M, Horst W: [Irradiation therapy of vertebral angionomas: results in 62 patients during the years 1939 to 1975 (author's transl).] Strahlentherapie 153:522525, 1977 (Ger)

31. Goldstein CL, Varga PP, Gokaslan ZL, Boriani S, Luzzati A, Rhines L, et al: Spinal hemangiomas: results of surgical management for local recurrence and mortality in a multicenter study. Spine (Phila Pa 1976) 40:656-664, 2015

32. Goyal M, Mishra NK, Sharma A, Gaikwad SB, Mohanty BK, Sharma S: Alcohol ablation of symptomatic vertebral hemangiomas. AJNR Am J Neuroradiol 20:1091-1096, 1999

33. Gross CE, Hodge CH Jr, Binet EF, Kricheff II: Relief of spinal block during embolization of a vertebral body hemangioma. Case report. J Neurosurg 45:327-330, 1976

34. Guarnieri G, Ambrosanio G, Vassallo P, Pezzullo MG, Galasso R, Lavanga A, et al: Vertebroplasty as treatment of aggressive and symptomatic vertebral hemangiomas: up to 4 years of follow-up. Neuroradiology 51:471-476, 2009

35. Guo C, Yan Z, Zhang J, Jiang C, Dong J, Jiang X, et al: Modified total en bloc spondylectomy in thoracic vertebra tumour. Eur Spine J 20:655-660, 2011

36. Haque MU, Wilson AN, Blecher HD, Reich SM: Lumbar hemangioma masking a plasma cell tumor-case report and review of the literature. Spine J 13:e11-e15, 2013

37. Harrison MJ, Eisenberg MB, Ullman JS, Oppenheim JS, Camins MB, Post KD: Symptomatic cavernous malformations affecting the spine and spinal cord. Neurosurgery 37:195-205, 1995

38. Heiss JD, Doppman JL, Oldfield EH: Brief report: relief of spinal cord compression from vertebral hemangioma by intralesional injection of absolute ethanol. N Engl J Med 331:508-511, 1994

39. Hekster RE, Endtz LJ: Spinal-cord compression caused by vertebral haemangioma relieved by percutaneous catheter embolisation: 15 years later. Neuroradiology 29:101, 1987

40. Heyd R, Seegenschmiedt MH, Rades D, Winkler C, Eich HT, Bruns F, et al: Radiotherapy for symptomatic vertebral hemangiomas: results of a multicenter study and literature review. Int J Radiat Oncol Biol Phys 77:217-225, 2010
41. Ide C, Gangi A, Rimmelin A, Beaujeux R, Maitrot D, Buchheit F, et al: Vertebral haemangiomas with spinal cord compression: the place of preoperative percutaneous vertebroplasty with methyl methacrylate. Neuroradiology 38:585-589, 1996

42. Inoue T, Miyamoto K, Kodama H, Hosoe H, Shimizu K: Total spondylectomy of a symptomatic hemangioma of the lumbar spine. J Clin Neurosci 14:806-809, 2007

43. Jayakumar PN, Vasudev MK, Srikanth SG: Symptomatic vertebral haemangioma: endovascular treatment of 12 patients. Spinal Cord 35:624-628, 1997

44. Jha B, Choudhary AK: Unusual cause of back pain in an adolescent patient: a case report and natural history of aggressive vertebral hemangioma in children. Pain Physician 11:687-692, 2008

45. Jiang L, Liu XG, Yuan HS, Yang SM, Li J, Wei F, et al: Diagnosis and treatment of vertebral hemangiomas with neurologic deficit: a report of 29 cases and literature review. Spine J 14:944-954, 2014

46. Jones JO, Bruel BM, Vattam SR: Management of painful vertebral hemangiomas with kyphoplasty: a report of two cases and a literature review. Pain Physician 12:E297-E303, 2009

47. Kato S, Kawahara N, Murakami H, Demura S, Yoshioka $\mathrm{K}$, Okayama T, et al: Surgical management of aggressive vertebral hemangiomas causing spinal cord compression: long-term clinical follow-up of five cases. J Orthop Sci 15:350-356, 2010

48. Kiroglu Y, Benek B, Yagci B, Cirak B, Tahta K: Spinal cord compression caused by vertebral hemangioma being symptomatic during pregnancy. Surg Neurol 71:487-492, 2009

49. Kulcsár Z, Veres R, Hanzély Z, Berentei Z, Marosfoi M, Nyáry I, et al: Rare angioproliferative tumors mimicking aggressive spinal hemangioma with epidural expansion. Ideggyogy Sz 65:42-47, 2012

50. Laredo JD, Reizine D, Bard M, Merland JJ: Vertebral hemangiomas: radiologic evaluation. Radiology 161:183-189, 1986

51. Lavi E, Jamieson DG, Granat M: Epidural haemangiomas during pregnancy. J Neurol Neurosurg Psychiatry 49:709_ 712,1986

52. Manning HJ: Symptomatic hemangioma of the spine. Radiology 56:58-65, 1951

53. McAllister VL, Kendall BE, Bull JW: Symptomatic vertebral haemangiomas. Brain 98:71-80, 1975

54. Mohan V, Gupta SK, Tuli SM, Sanyal B: Symptomatic vertebral haemangiomas. Clin Radiol 31:575-579, 1980

55. Murugan L, Samson RS, Chandy MJ: Management of symptomatic vertebral hemangiomas: review of 13 patients. Neurol India 50:300-305, 2002

56. Ogawa R, Hikata T, Mikami S, Fujita N, Iwanami A, Watanabe K, et al: Total en bloc spondylectomy for locally aggressive vertebral hemangioma causing neurological deficits. Case Rep Orthop 2015:724364, 2015

57. Raco A, Ciappetta P, Artico M, Salvati M, Guidetti G, Guglielmi G: Vertebral hemangiomas with cord compression: the role of embolization in five cases. Surg Neurol 34:164-168, 1990

58. Rades D, Bajrovic A, Alberti W, Rudat V: Is there a doseeffect relationship for the treatment of symptomatic vertebral hemangioma? Int J Radiat Oncol Biol Phys 55:178-181, 2003

59. Redekop GJ, Del Maestro RF: Vertebral hemangioma causing spinal cord compression during pregnancy. Surg Neurol 38:210-215, 1992

60. Robinson Y, Sheta R, Salci K, Willander J: Blood loss in surgery for aggressive vertebral haemangioma with and without embolisation. Asian Spine J 9:483-491, 2015

61. Roelvink NC, Kamphorst W, August H, van Alphen M, Rao BR: Literature statistics do not support a growth stimulating role for female sex steroid hormones in haemangiomas and meningiomas. J Neurooncol 11:243-253, 1991 
62. Schild SE, Buskirk SJ, Frick LM, Cupps RE: Radiotherapy for large symptomatic hemangiomas. Int J Radiat Oncol Biol Phys 21:729-735, 1991

63. Sharma D, Jain V, Rath GP: Asystole during percutaneous ethanol injection of symptomatic vertebral haemangioma. Anaesth Intensive Care 34:656-658, 2006

64. Slimani O, Jayi S, Fdili Alaoui F, Bouguern H, Chaara H, Fikri G, et al: An aggressive vertebral hemangioma in pregnancy: a case report. J Med Case Reports 8:207, 2014

65. Smith TP, Koci T, Mehringer CM, Tsai FY, Fraser KW, Dowd CF, et al: Transarterial embolization of vertebral hemangioma. J Vasc Interv Radiol 4:681-685, 1993

66. Song RX, Zhang YG, Zhang XS, Zheng GQ, Wang Y: [Onestage total en bloc spondylectomy and reconstruction via a single posterior approach for thoracic vertebral symptomatic hemangioma associated with spinal cord dysfunction.] Zhonghua Wai Ke Za Zhi 50:342-345, 2012 (Chinese)

67. Tekkök IH, Açìkgöz B, Sağlam S, Onol B: Vertebral hemangioma symptomatic during pregnancy-report of a case and review of the literature. Neurosurgery 32:302-306, 1993

68. Urrutia J, Postigo R, Larrondo R, Martin AS: Clinical and imaging findings in patients with aggressive spinal hemangioma requiring surgical treatment. J Clin Neurosci 18:209212, 2011

69. Yadav N, Prabhakar H, Singh GP, Bindra A, Ali Z, Bithal PK: Acute hemodynamic instability during alcohol ablation of symptomatic vertebral hemangioma: a prospective study. J Clin Neurosci 17:810-811, 2010

70. Yang ZY, Zhang LJ, Chen ZX, Hu HY: Hemangioma of the vertebral column. A report on twenty-three patients with special reference to functional recovery after radiation therapy. Acta Radiol Oncol 24:129-132, 1985

71. Yao KC, Malek AM: Transpedicular N-butyl cyanoacrylatemediated percutaneous embolization of symptomatic vertebral hemangiomas. J Neurosurg Spine 18:450-455, 2013

72. Yu W, Selvarajan S, Rosenberg AE: Vascular tumors of bone, in Deyrup AT, Siegal GP (eds): Practical Orthopedic
Pathology: A Diagnostic Approach. Philadelphia: Elsevier, 2015, pp 187-203

73. Yung BC, Loke TK, Yuen NW, Chan CC: Spinal cord compression caused by thoracic vertebral hemangioma involving only the posterior elements of two contiguous vertebrae. Skeletal Radiol 27:169-172, 1998

74. Zapalowicz K, Skora P, Myslinski R, Karnicki F, Radek A: Balloon kyphoplasty for painful C-7 vertebral hemangioma. J Neurosurg Spine 8:458-461, 2008

\section{Disclosures}

Dr. Groff reports a consultant relationship with DePuy Spine and Biomet Spine as well as royalty for development from Biomet Spine.

\section{Author Contributions}

Conception and design: all authors. Acquisition of data: Vasudeva. Analysis and interpretation of data: Vasudeva. Drafting the article: Vasudeva. Critically revising the article: all authors. Reviewed submitted version of manuscript: all authors. Approved the final version of the manuscript on behalf of all authors: Vasudeva.

\section{Supplemental Information}

Previous Presentations

Portions of this work were presented during an oral platform presentation at the DSPN Spine Summit 2016 meeting in Orlando, Florida, on March 18, 2016

\section{Correspondence}

Viren S. Vasudeva, Brigham and Women's Hospital, Harvard Medical School, 75 Francis St., AB-136, Boston, MA 02115. email: vvasudeva@partners.org. 